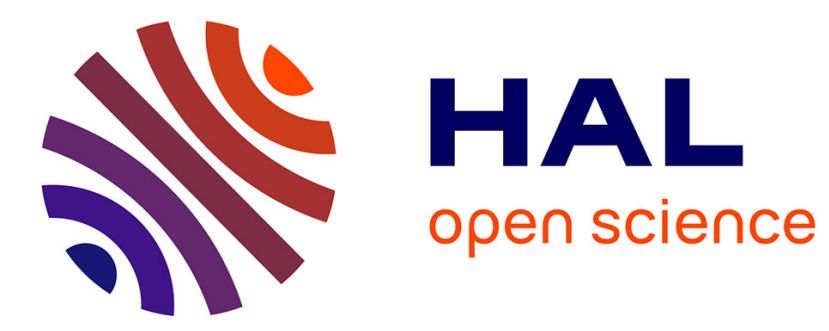

\title{
Westward migration of oceanic ridges and related asymmetric upper mantle differentiation
}

\author{
Françoise Chalot-Prat, Carlo Doglioni, Trevor Falloon
}

\section{To cite this version:}

Françoise Chalot-Prat, Carlo Doglioni, Trevor Falloon. Westward migration of oceanic ridges and related asymmetric upper mantle differentiation. Lithos, 2017, 268-271, pp.163-173. 10.1016/j.lithos.2016.10.036 . hal-02936297

\section{HAL Id: hal-02936297 \\ https:/ /hal.univ-lorraine.fr/hal-02936297}

Submitted on 15 Sep 2020

HAL is a multi-disciplinary open access archive for the deposit and dissemination of scientific research documents, whether they are published or not. The documents may come from teaching and research institutions in France or abroad, or from public or private research centers.
L'archive ouverte pluridisciplinaire HAL, est destinée au dépôt et à la diffusion de documents scientifiques de niveau recherche, publiés ou non, émanant des établissements d'enseignement et de recherche français ou étrangers, des laboratoires publics ou privés. 


\title{
Westward migration of oceanic ridges and related asymmetric upper mantle differentiation
}

\author{
Françoise Chalot-Prat $^{\mathbf{a}}$, Carlo Doglioni ${ }^{\mathrm{b}}$, Trevor Falloon ${ }^{\mathrm{c}}$ \\ ${ }^{a}$ Centre de Recherches Petrographiques et Geochimiques - Lorraine University, BP20, 15 rue Notre \\ Dame des Pauvres, F-54501 Vandoeuvre-les-Nancy Cedex, France. \\ ${ }^{b}$ Dipartimento di Scienze della Terra, Sapienza University, P.le A. Moro, 5, 00185 Roma, Italy and \\ Istituto Nazionale di Geofisica e Vulcanologia, Via di Vigna Murata 605, 00143 Roma, Italy \\ ${ }^{c}$ School of Physical Sciences, Discipline of Earth Sciences, University of Tasmania, Hobart, Tasmania \\ 7001, Australia
}

Corresponding author: Françoise Chalot-Prat francoise.chalot-prat@univ-lorraine.fr

\section{Highlights:}

1. Westward ridge migration induces higher mantle refertilisation of the western plate ...88

2. Upwelling residual mantle is abandoned eastward consistent with seismological asymmetry ... 91

3. Ridge migration provides permanently MORB mantle source from the west ...73

\section{Abstract}

Combining geophysical, petrological and structural data on oceanic mantle lithosphere, underlying asthenosphere and oceanic basalts, an alternative oceanic plate spreading model is proposed in the framework of the westward migration of oceanic spreading ridges relative to the underlying asthenosphere. This model suggests that evolution of both the composition and internal structure of oceanic plates and underlying upper mantle strongly depends at all scales on plate kinematics. We show that the asymmetric features of lithospheric plates and underlying upper asthenosphere on both sides of oceanic spreading ridges, as shown by geophysical data (seismic velocities, density, thickness, and plate geometry), reflect somewhat different mantle compositions, themselves related to various mantle differentiation processes (incipient to high partial melting degree, percolation/reaction and refertilisation) at different depths (down to $300 \mathrm{~km}$ ) below and laterally to the ridge axis. The fundamental difference between western and eastern plates is linked to the westward ridge migration inducing continuing mantle refertilisation of the western plate by percolation-reaction with ascending melts, whereas the eastern plate preserves a barely refertilized harzburgitic residue. Plate thickness on both sides of the ridge is controlled both by cooling of the asthenospheric residue and by the instability of pargasitic amphibole producing a sharp depression of the water-undersaturated solidus, its intersection with the geotherm at $\sim 90 \mathrm{~km}$, and incipient melt production right underneath the lithosphere-asthenosphere boundary (LAB). Thus the intersection of the geotherm with the waterundersaturated lherzolite solidus explains the existence of a low-velocity zone (LVZ). As oceanic lithosphere is moving westward relative to asthenospheric mantle, this partially molten upper asthenosphere facilitates the decoupling between lower asthenosphere and lithosphere. Thereby the westward drift of the lithosphere is necessarily slowed down, top to down, inducing a progressive decoupling within the mantle lithosphere itself. This intra-mantle decoupling could be at the origin of asymmetric detachment faults allowing mantle exhumation along slow-spreading ridges. Taking into account the asymmetric features of the LVZ, migration of incipient melt fractions and upwelling paths 
from the lower asthenosphere through the upper asthenosphere are oblique, upward and eastward. MORB are sourced from an eastward and oblique, near-adiabatic mantle upwelling from the lower asthenosphere. This unidirectional mantle transfer is induced by isostatic suction of the migrating spreading ridge.

\section{Key words}

Asymmetric oceanic lithosphere, Westward drift of the lithosphere, Migrating ridge, Mantle melting, Percolation-reaction and refertilization, Detachment fault and mantle core complex, Secondary lherzolite and upper mantle differentiation

\section{Introduction}

The theory of plate tectonics, the post-1960's version of continental drift (Wegener, 1915), proposes that the lithosphere (crust + uppermost mantle) is divided into a number of plates that can move over, as well as descend into, the underlying asthenosphere and even deeper. However, since the development of plate tectonics theory, the link between geodynamics and the compositional differentiation of lithospheric and asthenospheric mantles has received relatively little attention. Most commonly, both plates and underlying asthenosphere are treated in geophysical modelling as closed systems evolving separately with little mutual interaction. Petrological and structural studies of exposed mantle lithologies and experimental petrology demonstrate significant interactions between lithospheric and asthenospheric mantles at mid-oceanic spreading ridges. Moreover in recent years, geophysical observations of oceanic plates have demonstrated a significant asymmetry of the oceanic lithosphere on both sides of oceanic spreading ridge axis (Doglioni et al., 2003; Muller et al., 2008; Panza et al., 2010 and references therein) in terms of seismic velocities, density, thickness, and plate geometry (Fig. 1). These observations are fundamental and require an explanation that integrates the whole data in order to improve our understanding of how the lithosphere and asthenosphere interact at and near spreading ridges.

Since the 1960s, plate tectonics is conceived as driven either by active mantle upwelling ('bottom up' or alternatively 'ridge push') or alternatively by the negative buoyancy of slabs ('top down' or alternatively 'slab pull'). It is clear that creation of oceanic lithosphere and its subsequent subduction are fundamental mechanisms in governing the cooling of the Earth. In other words, the surface dissipation of both the Earth's internal primordial and radiogenic heat is tied with the re-entrance of the cold lithosphere along subduction zones to determine the cooling of the planet. However, the mechanisms determining mantle drag and mantle convection remain a matter of debate. The asymmetry of subduction zones (those directed to the west are steeper and faster, e.g., Doglioni et al., 2007; Riguzzi et al., 2010) and plate motion reconstructions relative to the mantle reference frame support a westerly-directed drift of the lithosphere relative to the underlying mantle, also called net rotation (as a mean value) or westward drift (Wegener, 1915; Holmes, 1944; Carey, 1958; Le Pichon, 1968; Bostrom, 1971; Moore; 1973; Ricard et al., 1991; Gripp and Gordon, 2002; Crespi et al., 2007; Cuffaro and Doglioni, 2007). The net rotation or the westward drift of the lithosphere requires both a decoupling at the lithosphere-asthenosphere interface and a mechanism driving this rotation (Doglioni et al., 2011; Doglioni and Anderson, 2015; Doglioni and Panza, 2015). The motion is not east-west, but along an undulated flow that varies from WNW to E-W to ENE trends, along the so-called 'tectonic equator' (Crespi et al., 2007). Proposed mechanisms involve either the negative buoyancy of the lithosphere (Ricard et al., 1991), or the astronomical drag induced by the Earth's rotation 
combined with tidal friction (Riguzzi et al., 2010). Potentially astronomical forces may interact with mantle convection resulting from the cooling of the Earth (Holmes, 1944; Carey, 1958; Scoppola et al., 2006).

The aim of our paper is to build an oceanic spreading model integrating existing compositional, structural and geophysical data across oceanic ridges and the underlying upper mantle. We show the interdependence between the oceanic spreading process, the upper mantle differentiation and plate kinematics driven by the westward drift of the lithosphere. Our model enables to integrate, in space and time, natural and experimental petrology results on upper mantle differenciation (down to $300 \mathrm{~km}$ depth) and oceanic, tholeiitic and alkalic, basalt genesis (Green et al., 2014; Green 2015; Green and Falloon, 2015 and references therein), and provides a mechanism for upper mantle geophysical stratification with lateral heterogeneity as evidenced by Thybo (2006).

We will use the well accepted terminology of geophysicists, i.e., upper asthenosphere as the equivalent of "petrological' asthenosphere" corresponding to the Low-Velocity Zone (LVZ), and lower asthenosphere as the equivalent of "petrological' sub-asthenosphere" that reaches about $410 \mathrm{~km}$ of depth (Green and Falloon, 1998). They are defined in terms of depth, thickness and composition later in this paper.

\section{Asymmetry on both sides of oceanic spreading axis and preliminary model}

Since the recognition of magnetic anomalies on both sides of oceanic ridges (Vine and Matthews, 1963), oceanic rift zones were considered as having symmetric features, and plate spreading as a symmetric geological process. As shown by Doglioni et al. (2003), observations on the bathymetry of ridge flanks (shallower eastward) of Pacific and Atlantic oceans and on variable rates of oceanic spreading (Muller et al., 1997; 2008; Mallows and Searle, 2012) contradict the concept of full symmetry. Panza et al. (2010) and Panza and Romanelli (2014) provided evidence for asymmetry in both shear wave velocity and thickness within mantle lithosphere and asthenosphere when comparing the two sides of most spreading ridges. In general, the old ( $>60 \mathrm{Ma})$ western lithospheric plates have a faster shear wave velocity and are thicker $(\approx 100 \mathrm{~km}$ versus $\approx 80 \mathrm{~km}$ in the eastern flank). Seismic tomography (Thybo, 2006; Panza et al., 2010; Schmerr, 2012; Panza and Romanelli, 2014) provides robust evidence of an asymmetric LVZ at depths from about $80-100 \mathrm{~km}$ down to $180-225 \mathrm{~km}$. The average Vs within the western LVZ is slower than the eastern one. The LVZ shape is itself asymmetric, being thicker and wider on the western side of ridges. Also passive continental margins and the related continent-ocean transition support a systematic asymmetry of rift zones (Lavier and Manatschal, 2006; Brune et al., 2014).

All these asymmetric features appear to be independent from the age of the oceanic lithosphere, although they become more prominent moving toward older lithospheric ages (Panza et al., 2010). These observations suggest that mantle compositions and related physical parameters such as rigidity $\mu$, density $\rho$ and their ratio $\mu / \rho$, are systematically different from one side to the other of a spreading ridge within both the lithosphere and the upper asthenosphere, i.e., the LVZ.

Panza et al. (2010) explain these observations as a result of the depletion of the upper asthenosphere, that evolves from pre-melting lherzolite into post-melting harzburgite composition below the oceanic ridge, while the ridge is moving westward relative to the asthenospheric mantle, i.e., in the hot-spot reference frame (Crespi et al., 2007). The role of ridge migration (Scheirer et al., 1998; Small and Danyushevsky, 2003; Doglioni and Panza, 2015) in producing an oceanic plate asymmetry is a key parameter of the model. To the east of the ridge, the lithospheric mantle (named also LID) would represent the residual product from partial melting of upwelling asthenosphere, 
131 abandoned and in the process of cooling after the ridge migration to the "west". Since ridges are shifting above a fertile asthenospheric mantle, there is a continuous supply of MORB source mantle beneath the migrating spreading ridge (Panza et al., 2010). This model, deduced from geophysical and kinematic data (Fig. 1), suggests that the westward drift of the lithosphere relative to the underlying asthenosphere is a global phenomenon, a concept that implies decoupling between lithosphere and asthenosphere occurring within the LVZ, i.e., in the upper asthenosphere.

Important questions that arise from the above observations are as follows:

138 i) How does oceanic lithospheric mantle form?

139 ii) How can the mantle lithosphere composition evolve differently on each side of the ridge?

140 iii) How to combine oceanic spreading and westward drift of the lithosphere? Could the detachment141 mode of seafloor spreading (Maffione et al., 2013; Whitney et al. 2013 and references therein), be the 142 visible major effect in the field?

143 iv) How does asthenosphere evolve in relation with oceanic lithosphere during plate spreading? What

144 controls the differentiation between lower and upper asthenosphere and the rather homogeneous 145 thickness $(\approx 125 \mathrm{~km})$ of the upper part?

146 v) How to combine the ascent of MORB source mantle from the lower asthenosphere according to experimental P-T-depth conditions (Green et al., 2014) with oceanic spreading and westward drift of the lithosphere?

149 vi) Is the oceanic lithosphere denser than the underlying asthenosphere?

3. Deciphering the compositional and physical evolution of the oceanic lithospheric mantle on both sides of a spreading ocean ridge

Lithospheric plates of slow spreading oceans (up to $4 \mathrm{~cm} / \mathrm{yr}$, e.g., Atlantic, Arctic, southwest Indian and Antarctic) are known to be mostly composed of mantle rocks. Volumes of extrusive and intrusive magmatic rocks, representative of the magmatic oceanic crust, remain minor (Cannat, 1993; ChalotPrat, 2005; Smith et al., 2008, 2012). Lithospheric mantle is thus the main component of the oceanic plate, which reinforces the major role of oceanic mantle for understanding the nature and construction of the ocean floor. For this reason the following discussion (below) will focus firstly on the physical then secondly on the petrological features of the lithospheric mantle.

\subsection{General physical features and composition of oceanic lithosphere}

The oceanic lithosphere is deeply fractured at the ridge axis. This major fracture network reaches the top of the ductile layer in the lithosphere, and two plates, A and B, form and spread apart. The western plate A always moves westerly faster than the eastern plate B (Fig. 2) as shown by Crespi et al. (2007). In our model, due to the westward drift of the lithosphere (Le Pichon, 1968; Doglioni et al., 2003), both plates move to the west, the western plate A at VA and the eastern plate B at VB, being $\mathrm{VA}>\mathrm{VB}$ (Fig. 2). The oceanic ridge moves west at $\mathrm{Vr}=(\mathrm{VA}+\mathrm{VB}) / 2$. Plate growth rate is due to the difference between $V A$ and $V B$. Thus the separation between points on each plate increases at the half spreading rate $(\mathrm{hS})$ which is given by $(\mathrm{VA}-\mathrm{VB}) / 2$. $\mathrm{Vr}$ is always faster than $\mathrm{hS}$.

The thickness of the oceanic lithosphere can be estimated from geophysical data including seismic, gravity, and electrical conductivity It can also be inferred from geotherm/lherzolite solidus intersection based on experimental studies at controlled $\mathrm{P}, \mathrm{T}$ and water contents.

Geophysical data show lithospheric thickness decreasing towards ridge axes above shallowing asthenosphere. However we do not think that the lithosphere-asthenosphere boundary (LAB) reaches the base of the newly formed basaltic crust at fast spreading ridges, nor approaches the sea floor at 
magma-starved slow-spreading ridges. This view is based on the petrology (phase assemblages), chemical compositions and isotopic compositions of peridotites sampled from rifted margins, ridge/transform intersections and slow-spreading ridges. Only lithospheric (secondary harzburgite or secondary lherzolite; see Piccardo et al., 2007b), but not asthenospheric mantle compositions have been identified either at the bottom of rift axis in slow-spreading active and fossil oceans (e.g., Seyler and Bonatti, 1997; Dijkstra et al., 2001; Takahashi, 2001; Tartarotti et al., 2002; Müntener et al., 2004; Piccardo et al., 2004, 2007a b, 2014; Kaczmarek and Müntener, 2008, 2010; Rampone et al., 1997, 2005, 2008; Rampone and Borghini, 2008; Warren and Shimizu, 2010; Muntener et al., 2010; Piccardo and Garnieri, 2010; Rampone and Hofmann, 2012; Warren, 2016), or below oceanic crust in fast-spreading active and fossil oceans (Dick and Natland, 1996; Abily and Ceuleneer, 2013). The depth of the LAB under the ridge may be inferred in two ways: 1. estimating the depth of melt segregation for parental MOR picrites or basalts and 2. by the $\mathrm{P}, \mathrm{T}$ conditions recorded in ridge peridotites (including their $\mathrm{P}, \mathrm{T}$ decompression paths in some cases). Indeed experimental results (Fig. 3) demonstrate that parental MOR picrite segregation from residual peridotite occurs mostly between 2 to $1.6 \mathrm{GPa}$ (up to $2.2 \mathrm{GPa}$; down to $1.1 \mathrm{GPa}$ ), thus between 55 to $45 \mathrm{~km}$ depth (down to $65 \mathrm{~km}$; up to $30 \mathrm{~km}$ ), around $1400^{\circ} \mathrm{C}$ (up to $1430^{\circ} \mathrm{C}$ ) from a trace element depleted lherzolite (Eggins, 1992a,b; Falloon et al., 2007a,b; Green et al., 2001; Green and Falloon, 2005; Green et al., 2014; Green and Falloon, 2015). Magma genesis produces mantle residual peridotite less dense than the asthenospheric protolith, accreting above its asthenospheric source and potentially subject to percolation-reaction of new magma ascents, giving birth to a refertilized constantly growing oceanic lithospheric mantle. From experimental results on liquid compositions in equilibrium with spinel and/or plagioclase lherzolite assemblages (Falloon et al., 2007a, b; Chalot-Prat et al., 2010; 2013), analogous to natural oceanic mantle samples, the oceanic lithospheric mantle thickness at the ridge is at least $20 \mathrm{~km}$ and up to $40 \mathrm{~km}$ in thickness. Note that density differences are due to chemical/mineralogical differences but also to temperature differences (e.g., residual mantle temperature has been reduced by the lost of the latent heat of melting). Thus determining density differences is subject to significant uncertainties.

Laterally on both sides of the ridge axis, seismic data show a progressive thickening of oceanic mantle lithosphere until around $80-100 \mathrm{~km}$ maximum, equivalent to $3 \mathrm{GPa}$ of pressure. This thickening is assumed to derive first from the addition of the cooled uppermost part of asthenosphere (below $1100^{\circ} \mathrm{C}$; Green and Falloon, 2005; Green et al., 2014). Green and Falloon (2005) and Green et al. $(2010,2011,2014)$ have shown experimentally that the lithospheric mantle thickness depends on its water storage capacity (Fig. 3). Indeed at pressures greater than 2.5 to $3 \mathrm{GPa}$ ( 80 to $100 \mathrm{~km} \mathrm{depth}$ ), instability of pargasite causes a sharp drop in the water storage capacity of fertile lherzolite, and for water content greater than $\sim 200 \mathrm{ppm}$ in the lithosphere, the mantle solidus is depressed at 2.5-3 GPa along the geotherm. In both cases partial melting can explain both the thickness of the oceanic lithosphere and the occurrence of a LVZ just below the LAB. Therefore from a petrological point of view, the LAB detected by the slowing of seismic waves is the intersection of the geotherm with the vapour-undersaturated lherzolite solidus, and the LVZ is a layer in which there is incipient melt (probably $<1-2 \%$ melt).

As far as it concerns the depth/temperature of the base of the oceanic lithosphere outside the ridge $\left(>500 \mathrm{~km}\right.$ ), the model of Afonso et al. (2007) predicts $1300^{\circ} \mathrm{C}$ at $105 \mathrm{~km}$ depth. This temperature is somewhat too high according to experimental data of Green et al. $(2010,2014)$, showing that a "wet" ( $>200$ ppm $\mathrm{H}_{2} \mathrm{O}$ ) oceanic lithospheric mantle is above its solidus below $80-100 \mathrm{~km}$ if temperature is higher than $1000{ }^{\circ} \mathrm{C}$ (Fig. 3). Below this depth, this is the LVZ, thus the upper asthenosphere. An incipient melt is present, the melt fraction being determined primarily by the water and $\mathrm{CO}_{2}$ contents. 
219 This melt has low permeability (i.e. can only move slowly by porous flow), but has a large effect on

220 seismic and rheological properties.

221

222

223

224

225

226

227

228

229

230

231

232

233

234

235

236

237

238

239

\subsection{How oceanic mantle lithosphere of the western limb of the ridge axis becomes thicker and denser compared to the eastern limb?}

\subsubsection{Intra-lithospheric mantle decoupling}

In this section we will focus on the modalities of mantle mass transfer upwards and laterally within both spreading plates in the framework of the westward drift of the lithosphere. Oceanic mantle lithosphere is created at the ridge through accretion of residues above the asthenospheric partial melting area. These residues are successively transferred upwards and laterally at hS rate within the mantle lithosphere on each side of the ridge (Fig. 2). As $\mathrm{Vr}$ is higher than hS, the transfer rate of successive residues above the melting area is slower than the westward velocity of the melting area itself. Accordingly, mantle exhumed at the bottom of any active axial ridge is always older than the basaltic volcanoes emplaced at the axial ridge (Bonatti et al., 2003). It is the same for intrusive gabbro bodies which move upwards and laterally, driven by and with the upwelling of the host-mantle: for instance, for $\mathrm{hS}=2 \mathrm{~cm} / \mathrm{yr}, \mathrm{Vr}=4 \mathrm{~cm} / \mathrm{y}$ and a mantle residue initial depth of $\mathrm{Di}=40 \mathrm{~km}$, the mantle residue takes t1 $2 \mathrm{Ma}(\mathrm{t} 1=\mathrm{Di} / \mathrm{hS})$ to ascend and to be exhumed at the surface. Thus active volcanoes at the ridge axis are about 2 Ma younger than the mantle on which they are formed. Besides, while this mantle residue is rising up to the ocean floor, the ridge itself with the uppermost part of the lithosphere will have moved $(\mathrm{t} 1 * \mathrm{Vr}) 80 \mathrm{~km}$ westward. However it may be possible that due to 'second-stage melting', the extra buoyancy added to the residue may accelerate the upwelling - in which case some residue may be younger than $2 \mathrm{Ma}$.

Therefore, besides the notion that asthenosphere is moving "eastward" relative to the lithosphere (or more precisely along the flow lines parallel to the undulate tectonic equator of Crespi et al., 2007 and Cuffaro and Doglioni, 2007), the westward drift of the lithosphere is necessarily slowed down, top to down, inducing a decoupling within the mantle lithosphere itself. This is visualized on the model (Fig. 2) with the progressive top-down eastward shifting of the "half-spreading residues" relative to each other within both plates. This decoupling would be progressive such that the top of the melting area would be somewhat delayed relative to the top of the axial ridge, even if they are interdependent.

Normal faults are the natural feature associated with rift zones and as indicated by rock mechanics, their mean dip is around $60^{\circ}$. Lower dips may naturally result from a decrease of friction due to the high heat flow and moving into shear zones within the underlying ductile layer. Besides faults and fractures may dip predominantly in one direction if spreading is asymmetric. Indeed the half spreading rate is often slighlty asymmetric (Mueller et al., 2008), but this is related not to the velocity of plates relative to the mantle, but to the velocity of the ridge which sometimes is not exactly $(\mathrm{VA}+\mathrm{VB}) / 2$; it may be $(\mathrm{VA}+\mathrm{VB}) / 1.95$ or $(\mathrm{VA}+\mathrm{VB}) / 2.05$ etc. Therefore faster and larger spreading may occur in one flank without varying the relative velocity of the two plates with respect to the mantle. This can be explained by the lateral viscosity variations in the flanks right beneath the ridge. Therefore, ridgerelated faults and associated fractures would dip mainly "eastward" and be convex upwards since the westward drift is faster upwards, but their dip may also be opposite due to the half-spreading process. This is the geometry of detachment faults, i.e., large offset low-angle faults capping the eastern (rarely western) side of oceanic mantle core complexes (OCC ; Smith et al., 2008, 2012; MacLeod et al., 2009; Reston and Ranero, 2011; Mallows and Searle, 2012; Whitney et al., 2013; Maffione et al., 2013) and extending along steep faults probably rooted in a melt-rich zone. They are responsible for 
exhumation of mantle and plutonic rocks onto the seafloor in the footwall of normal faults, whereas extrusion of basalt occurs on the hanging wall.

This intra-mantle decoupling within the lithosphere means also that even a mid-oceanic ridge and its related fracture network shift probably westward within the lithosphere, moving itself westward relative to the asthenosphere. This cannot be visible from the surface, and this is why general symmetry of magnetic stripes on the oceanic sea floor is preserved. However Carbotte et al. (2004) and Mallows and Searle (2012) note a westward shift of volcanic activity with time along the active Mid-Atlantic ridge axis. The geological maps of Mallows and Searle (Fig. 4; 2012) and Smith et al. (Fig. 4; 2012) show that most OCC outcrops on the western side of the ridge and that spreading rates are asymmetric with faster spreading on western plates. According to Whitney et al. (2013 and references therein), OCC account for $60 \%$ to $100 \%$ of the total plate spreading, showing that tectonic process is the main driver of mantle exhumation in the oceans and of heat and mass transfer in the Earth. Furthermore, Maffione et al. (2013) introduce the concept of detachment-mode of seafloor spreading. Moreover, the usual sill shape of gabbro intrusive bodies both at multimetric and multikilometric scale (Henstock et al., 1993 and references therein; Chalot-Prat, 2005) testifies subhorizontal magma injections within weakness zones of lithospheric mantle, supporting intra-mantle decoupling during ocean spreading. Volcanoes grow on the topmost part of the hangingwall of these large detachment faults, structuring hangingwall rider blocks (Whitney et al., 2013; Maffione et al., 2013 and references therein). Small-scale decoupling occurs between the base of volcanoes just emplaced and underlying mantle or/and gabbro bodies in the process of exhumation. This decoupling occurs on both sides of relief where eruptions take place, underlining a pseudo-symmetric spreading (Chalot-Prat, 2005).

\subsubsection{Asymmetric evolution of lithospheric mantle compositions and physical parameters on each side of the ridge}

The variation of Vs between the two sides of the oceanic ridge should have an explanation in terms of composition related to the different kinematics. As the melting area moves westward with the migrating spreading axis, the eastern plate B incorporates successively the abandoned depleted eastern parts of the ridge. It undergoes a relatively brief time of refertilization by ascending MORB and its composition remains close to a harzburgitic residue and is relatively Fe-poor. At the same time, harzburgitic residues are also continuously added to the western plate A, but, in contrast to the eastern plate, they are also continuously percolated by MORB as the ridge is moving westward above the underlying melting area linked to the ridge location. Thus the composition of the western plate $\mathrm{A}$ is that of a strongly refertilized harzburgite, thus a secondary lherzolite. An outcropping example could be the lherzolites from the Lanzo oceanic mantle area (Piccardo et al., 2007, and references therein). Therefore lithospheric mantle of the plate $\mathrm{A}$ is continuously re-enriched in $\mathrm{Fe}$ and $\mathrm{Ca}$, whereas lithospheric mantle of the plate $\mathrm{B}$ remains a harzburgitic residue barely re-enriched in $\mathrm{Fe}$ and $\mathrm{Ca}$.

Nevertheless as $\mathrm{Vr}>\mathrm{hS}$, the axial ridge is moving westwar within the lithosphere itself, and the western plate A is progressively incorporated within the eastern plate $\mathrm{B}$. This means that the plate $\mathrm{B}$ composition will become somewhat more refertilized than presented above. However the overall consequence is that the western plate $\mathrm{A}$ is thicker, always richer in $\mathrm{Fe}$ and thus denser than the eastern plate $\mathrm{B}$, resulting in a first order asymmetry in composition between the two plates.

In addition, if the westward drift is producing intra-lithospheric deformation preferentially on the western plate - then we might expect easier and more abundant pathways for off-axis magmatism and hence off-axis melt impregnation and channelling. Some of the upwelling diapirs may lose part of their melt fraction before arriving directly under the ridge axis. Evidence for this could be an 
asymmetry in abundance of off-axis seamounts (i.e. volcanic chains on western plate as in Shen et al., 1993, White et al., 1998). If this off-axis process occurs - then there will be less melt arriving directly under ridge axis - and hence the eastern flank will receive long-term less fertilised residue than the western flank.

is higher than $\rho \mathrm{B}$ (previous paragraph), $\mu \mathrm{A}$ must be much higher than $\mu \mathrm{B}$. Since the modulus of rigidity of $\mathrm{Fe}$ is around 3 to 4 times higher than that of $\mathrm{Mg}$ and $\mathrm{Si}$, the rigidity of rocks is expected to be enhanced if they are richer in Fe-rich minerals (Fyfe, 1960; Jordan, 1979). Thus higher $\mu \mathrm{A}$ compared to $\mu \mathrm{B}$ is an expected natural consequence of enhanced melt refetilization under the western plate A during westward migration of the spreading ridge.

\section{Deciphering the physical and compositional evolution of the asthenosphere below a spreading oceanic lithosphere}

\subsection{Lower asthenosphere}

The lower asthenosphere is subsolidus garnet lherzolite, about $180 \mathrm{~km}$ thick (230 to $410 \mathrm{~km}$ depth) overlying the Transitional Zone beginning at $\sim 410 \mathrm{~km}$ (Anderson, 2007; 2010; Schmerr, 2012). From the top to the bottom of this layer, seismic waves gradually increase their speed with respect to the LVZ. Vs is much higher than in the upper asthenosphere and more or less similar to that of the lithosphere (Panza and Romanelli 2014). Its mineralogical and chemical composition is inferred from experimental petrology on MORB genesis (Green et al., 2014; Green, 2015), being the N-MORB mantle source located below $230 \mathrm{~km}$. It is a fertile garnet lherzolite, depleted in the most incompatible trace elements, with $\geq 200 \mathrm{ppm} \mathrm{H}_{2} \mathrm{O}$ and with incipient melt at $\leq 7 \mathrm{GPa} / 230 \mathrm{~km}, 1490^{\circ} \mathrm{C}$. As shown in Fig. 3, an oceanic intraplate geotherm joins the mantle adiabat at about $230 \mathrm{~km}$ depth defining the base of the upper asthenosphere. The lower asthenosphere may migrate upwards as diapirs within the $230-100 \mathrm{~km}$ including very small, relatively immobile, near-solidus melts $(0.05-0.1 \%$ of melting).

\subsection{Upper asthenosphere}

Within the upper part (80-220 km depth) of the asthenosphere, i.e., the LVZ, Vs is slower in the western than in the eastern side of the ridge, the reverse of what it is observed in the oceanic lithosphere (Panza et al., 2010). We infer that during its transfer from west to east below the oceanic lithosphere, the eastern part of upper asthenosphere becomes somewhat Fe-depleted by incipient melting (Fig. 2) inducing a density decrease for a potentially similar value on rigidity from one side to the other of the axis. Moreover as shown by experiments of Conder and Wiens (2006), Hammond and Toomey (2003) and Green et al. (2014), the western part of the upper asthenosphere is hotter and/or richer in $\mathrm{H}_{2} \mathrm{O}+\mathrm{CO}_{2}$ than its eastern part and includes higher melt fractions inducing a rigidity decrease in the western side. It follows that to the "west" of a spreading ridge, both the oceanic lithospheric mantle (down to $90-100 \mathrm{~km}$ ) and the upper asthenosphere (down to $230 \mathrm{~km}$ ) should be more fertile and denser than the "eastern" part. Let us remember that in both mantle layers, density is determined not only by mantle fertility and Fe-enrichment, but also by the pargasite content in the lithospheric mantle and by percentage of melt within the upper asthenospheric mantle.

The LVZ has been seismically recognized below all oceans, both beneath the "western" and the "eastern" plates. It has a very small aspect ratio (thickness: $130 \mathrm{~km}$; length in spreading direction: $6^{*} 10^{3} \mathrm{~km}$ below the Atlantic to $11^{*} 10^{3} \mathrm{~km}$ below the Pacific). Experimental results (Fig. 3) show that the upper asthenosphere corresponds petrologically to a mantle layer including small interstitial melt fractions (i.e. 0.05 to $0.1 \%$ ). According to Doglioni et al. (2005), the degree of partial melting would 
503 be increased (up to $1.5 \%$ ) by shear heating (more than $100^{\circ} \mathrm{C}$ ) generated by decoupling between

504 lithosphere and lower asthenosphere (Fig. 3) and with largest contribution i.e. largest E-W relative movement at $\sim 230 \mathrm{~km}$ depth. It may be alternatively due to higher $\mathrm{H}_{2} \mathrm{O}$ content in the mantle (Bonatti, 1990; Ligi et al., 2005).

Moreover, seismic images from Panza and Romanelli (2014) show an asymmetric shape of the LVZ, thicker and more elongated westward ( $2 / 3$ in volume) than eastward (1/3 in volume) of ridge axis in all oceans. This spectacular and permanent asymmetry of the LVZ shape raises the question not only of the origin of partial melting, but also of its much greater development below the western part of the oceans. From experimental results (Fig. 3), the presence of these very small melt fractions have two distinct origins depending on the $\mathrm{H}_{2} \mathrm{O}$ content of the mantle sources: 1- below the lithosphere-asthenosphere boundary (LAB) and far away from the ridge $(>500 \mathrm{~km})$ : because of destabilization of amphibole, below $2.5-3 \mathrm{GPa} / 80-100 \mathrm{~km} / 1000-1100^{\circ} \mathrm{C}$, when "wet" $(>200 \mathrm{ppm}$ $\mathrm{H} 2 \mathrm{O}$ ) oceanic mantle lithosphere, i.e. a subsolidus pargasite-bearing garnet lherzolite cools, subsides and becomes asthenosphere, i.e. a pargasite-out garnet lherzolite with incipient melting. 2- above the lower-upper asthenosphere boundary: during adiabatic $\left(\approx 1490-1450^{\circ} \mathrm{C}\right)$ "dry" $(<200 \mathrm{ppm} \mathrm{H2O})$ ascent of the lower asthenosphere from $\geq 230 \mathrm{~km} / \geq 7$ GPa towards the MORB genesis area, i.e. $65-45 \mathrm{~km} / 2$ $1.6 \mathrm{GPa}$ below the ridge axis. Let us note that if the first partial melting origin corresponds to a rather static process linked only to the permanent thickening of the lithospheric mantle, the second is synchronous with a dynamic process of partially molten transfer of matter, both being imaged by the LVZ.

In parallel, the LVZ asymmetry suggests that the on-going ascent of partially molten mantle from lower asthenosphere is oblique, and not vertical, as already proposed by Carbotte et al. (2004). Taking into account its dimension, the ascent would be initiated around some thousands kilometers "west" from the ridge (Fig. 2), and driven by a suction effect towards the shallow area below the spreading ridge moving "westward", due to the removal of the overlying lithosphere and the consequent asthenospheric isostatic compensation.

Nevertheless according to the entrance angle of lower asthenosphere into upper asthenosphere, this lateral and upward mass transfer is more or less counteracted by the relative "eastward" horizontal mantle flow linked to the net rotation of the lithosphere, whose origin can be ascribed either to lateral viscosity variation (e.g., Ricard et al., 1991) or to the Earth's rotation (Scoppola et al., 2006; Riguzzi et al., 2010). Two different paths of transfer would exist. The main path involving the largest mantle volume follows a very low angle trajectory, barely deviated in passing below the spreading ridge; it would concern the mantle flux emerging rather far laterally (more than $500 \mathrm{~km}$ ?) from the spreading centre. From experimental results (Fig. 3), this mantle flux crosscuts the intraplate geotherm, modified by shear heating, and undergoes incipient to low degrees of partial melting (up to $4 \%$ down to $80-100$ $\mathrm{km}$ deep / 2.5-3 GPa, Green and Falloon, 2005). The other path is single inasmuch as, all things (composition, flowing velocity, temperature, pressure) being equal, a more opened entrance angle of mantle flux at a shorter distance from the ridge ( $500 \mathrm{~km}$ or less?) enables it to be mainly monitored by the suction effect coming from the strongly depressurized shallow area below the spreading ridge. This single path is assumed to be the one producing MORB after 15-20\% melting between 65 and 45 $\mathrm{km}$ depth ( 2 to $1.6 \mathrm{GPa}$ ) (see section 5.1 below). Indeed at small-scale, we suggest that convective eddies form by peeling off the upper surface of the lower asthenosphere and ascend driven by buoyancy and rheology contrast with the upper asthenosphere. These ascending eddies would become 'isolated' or encapsulated by a cooling rind/skin as the temperature contrast increases between eddy core and ambient mantle, forming diapirs. These eddies/diapirs move obliquely towards the shallow area below the spreading ridge where they are tapped by fracturing at the rift. 
"Eastward" of the ridge, because of the "westward" drift of the lithosphere, the suction effect fades and mantle melting progressively mitigates top to bottom to become quite insignificant at more than $1000 \mathrm{~km}$ from the ridge. Accordingly in this model, off-axis melt lenses on the eastern side of the East Pacific Ridge (Canales et al., 2012; Toomey, 2002, 2012) witness the asthenospheric partial melting zone underlying the ridge just before eastward abandonment due to the westward migration of the ridge.

According to this new scenario, the westward drift of the lithosphere and the related oceanic plate spreading have a strong mechanical effect on lateral (several thousands kilometers long) and upward (from 230 to $45 \mathrm{~km}$ depth) mantle mass transfer below the western plate A. This effect appears as extremely relevant in terms of mass transfer and is synchronous with partial melting and percolation/reaction processes, and thus mantle differentiation.

Therefore, as already inferred by Green et al. (2014) and Green (2015), the upper asthenosphere mantle composition is heterogeneous at a small scale, being influenced from below by the ascending lower asthenosphere and from above by the oceanic lithosphere during its journey and related process of thickening. In other terms, from $230 \mathrm{~km}$ to $90-100 \mathrm{~km}$, the upper asthenosphere should be a mantle layer including incipient melt fractions coming from two distinct mantle sources: the lower asthenosphere, the "dry" lherzolitic source of MORB on one hand; the lowermost part of lithosphere, made of harzburgitic residues produced below the ridge axis, more (westward) or less (eastward) refertilized and "wet" once accreted to the lithosphere.

All these data confirm that the asthenosphere forms a whole, 300-320 km thick, with a lower "nearly dry" ( $\left.\sim 200 \mathrm{ppm} \mathrm{H}_{2} \mathrm{O}\right)$ solid part $(\approx 185 \mathrm{~km}$ thick; $2 / 3$ in volume) and an upper "relatively wet $\left(>200 \mathrm{ppm} \mathrm{H}_{2} \mathrm{O}\right)$ solid + incipient melt" part $(\approx 125 \mathrm{~km}$ thick; $1 / 3$ in volume), the latter interacting with the overlying lower lithosphere. The existence of the asymmetric LVZ below the oceans indicates that below divergent plates, upwards and "eastward" transfer of lower asthenosphere is more active than elsewhere, accelerating its replacement by eastward lateral mantle flow coming from below the adjoining continents and related passive continental margin located to the "west" of a given ocean. So before flowing below and interacting with oceanic lithosphere, the upper asthenosphere underwent an earlier history of interaction with continental lithosphere, hence adding further chemical heterogeneity to intraplate mantle sources.

5. How to understand, within the framework of plate tectonics, the coexistence of mid-oceanic basalt and oceanic intraplate basalt mantle sources within the asthenosphere?

\subsection{Location of mid-oceanic basalt mantle sources}

Experimentally (Fig. 3), MORB are shown to be sourced from a roughly adiabatic (1490 to $\left.1430^{\circ} \mathrm{C}\right)$ upwelling of the uppermost part $(250-230 \mathrm{~km})$ of lower asthenosphere with melt fraction increasing dramatically above its anhydrous solidus $\left(3 \mathrm{GPa} / \sim 100 \mathrm{~km} ; 1450^{\circ} \mathrm{C}\right)$. MORB melt segregation occurs at 15-20\% melting between 2 and $1.6 \mathrm{GPa}$ ( 65 to $45 \mathrm{~km}$; Green and Falloon, 2005; Falloon et al., 2007b) within the so called "melting area" below the ridge axis in our model (Fig. 2).

The MORB mantle source composition is lherzolitic and fertile in terms of mineral assemblage and major element contents (Green and Falloon, 1998; 2005). However both trace element contents and $\mathrm{Nd}-\mathrm{Sr}-\mathrm{Pb}$ isotopic signatures are those of a mantle depleted in the most incompatible trace elements, interpreted as representative of a residual mantle composition. This decoupling between major and trace element composition interpretations is explained considering that the MORB source is itself a secondary lherzolite coming from the refertilization of a mantle residue by melts extracted from an already trace element depleted lherzolitic mantle (Frey and Green, 1974; Piccardo et al., 2007), or an 
eclogitic magmatic crust (Eller et al., 2000), or recycled components (e.g. oceanic crust, Eiler et al., 2000; or metasomatized oceanic lithosphere, Niu et al. 2002; Shimizu et al., 2015), or a mix (Rosenthal et al., 2014). So our model assumes that the uppermost part of the lower asthenosphere is a secondary lherzolite, being the refertilization mostly provided from the recycling of W-directed subducting oceanic lithospheric slabs (Rosenthal et al., 2014; Doglioni and Anderson, 2015; Green, 2015).

As shown by our model, the unique and unidirectional path of transfer of a mantle with a MORB source signature, combined with the westward drift of the lithosphere and of the spreading ridge itself, highlights the systematic and permanent identical replacement of the MORB mantle source within the same P-T conditions of ascent and partial melting, which fits with the observed relative compositional homogeneity of MORB (dominant N-MORB) through geological times. This compositional homogeneity testifies itself for an absence of significant interactions of this oblique succession of mantle diapirs (Green, 1971) crosscutting the surrounding upper asthenosphere, and therefore for the relatively high velocity of such mantle diapirs driven by the suction effect of the spreading ridge. Diapir buoyancy driven by density, rheology and isolation from wall-rock reaction, is probably more a consequence of increasing temperature contrast if the diapir is near adiabatic i.e garnet lherzolite with incipient melt into a rind of spinel lherzolite to plagioclase lherzolite (foliated to mylonitic).

\subsection{Location of oceanic intraplate basalt mantle sources}

As summarized by Green and Falloon (1998; 2005), Green et al. (2014), Green (2015) and Green and Falloon (2015), intraplate magmas, including oceanic intraplate basalts (or "hot spots" basalts), range from olivine melilitites and nephelinites, to olivine-rich basanites and finally to alkali basalts and olivine tholeiites. Experimentally, these basalts represent low degree (2 to $10 \%$ ) melts from mantle sources located within the uppermost asthenosphere on $50 \mathrm{~km}$ thickness $(\approx 110-160 \mathrm{~km} \mathrm{depth}$; $\approx 3.3$ to $5 \mathrm{GPa})$ or only $20 \mathrm{~km}$ thickness $(\approx 105-125 \mathrm{~km}$ depth; $\approx 3$ to $4 \mathrm{GPa})$ depending on the considered geotherm ("intraplate" or "intraplate+ shear heating effect"; Fig. 3). This upper asthenospheric source mantle is lherzolitic as the MORB mantle source and thus fertile in terms of mineral assemblage and major element contents, but above all rather enriched, and not depleted as the MORB source, in water $(>0.02 \%)$ and in the most incompatible trace elements. As inferred in the previous chapter, they are secondary lherzolites in which refertilization of mantle residues can have two distinct origins. On one hand the lherzolites could derive from destabilization $(\geq 90-100 \mathrm{~km}$ depth) of the lowermost part of the subsiding oceanic lithosphere far from the axial ridge. This result validates the hypothesis of an origin of some intraplate basalts from the lower lithospheric mantle in terms of composition (Anderson, 2010, and references therein). In that case, mantle metasomatism occurred below the spreading ridge by percolation/reaction of lithospheric mantle by MORB a rather long time ago. On the other hand, these secondary lherzolites could derive from metasomatism of lower asthenospheric material ascending throughout the upper asthenosphere along the main path with a very low angle trajectory (Fig. 2; see $\S 4.2$ for explanations). In that case, metasomatism results from successive percolation/reaction of incipient melts with mantle constantly on the move laterally. Nevertheless the Vs variations in the LVZ from one side to another of the ridge axis (cf. § 4.2) suggests that the uppermost mantle fertility is somewhat reduced eastward.

Besides the $\mathrm{Nd}-\mathrm{Sr}-\mathrm{Pb}$ isotopic signatures of intraplate basalts attest for mantle sources also metasomatized at some point in their long history by continental lithospheric products (Pilet et al., 2005; 2008; 2011). Notice that most Pacific, but also Indian "hot spots" basalts (dominant alkali intraplate basalts) are on the western or south-western plates relative to their respective axial ridges, thus are sourced within the upper asthenosphere having previously interacted with western adjoining 
638 and overlying continental plates. Such an interaction may be a candidate for explaining this continental imprint on intraplate basalt mantle sources, coherently with the relative "eastward" mantle flow.

\section{Towards an alternative oceanic plate spreading model for a polarized plate tectonics}

To date, a number of geophysical data at different scales demonstrate asymmetry of oceanic plates, whereas mantle petrologists still conceive mantle differentiation as a symmetric process on both sides of divergent plate boundaries and the underlying asthenosphere. To resolve this inconsistency, combination of updated geophysical, structural and petrological data on oceanic upper mantle (down to about $300 \mathrm{~km}$ ) and also related concepts on mantle and magma genesis and plate kinematics, leads to the development of an oceanic spreading model where both the growing oceanic lithospheric mantle and the underlying upper asthenospheric mantle are to varying degrees asymmetric in composition. Our model takes place in the frame of the westward drift of the lithosphere, which means that oceanic ridges migrate laterally to the "west" relative to the asthenospheric mantle, and thus are always moving over a fertile mantle.

From the geophysical data, the asymmetry concerns bathymetry of the ridge flanks (less steep eastward), plate velocity rates (slower for the eastern one), thickness of plates (thinner eastward), and faster shear wave velocity in the western lithosphere. It comes that plates on each side of the ridge differ in density as well as rigidity, thus in composition, and thereby in growing conditions of mantle lithosphere at the axial ridge.

To understand from a petrological but also kinematic point of view the aforementioned asymmetry, mantle lithosphere and mantle asthenosphere were examined separately, even if they are interdependent.

From natural and experimental data, three processes, two just below and one outside the spreading ridge, are known to generate compositional heterogeneity of oceanic mantle lithosphere of both plates: 1) sub-ridge accretion of partial melting residues formed by melt segregation from mantle asthenosphere upwelling; mantle lithosphere thickness at the axial ridge is estimated, via experimental results on mantle phase equilibrium, between 30 to $80 \mathrm{~km}$; 2) melt-rock reactions or mantle metasomatism by basaltic melt percolation through previously accreted residues below the ridge, inducing refertilisation and secondary lherzolite formation; 3) capture and addition of asthenospheric mantle to the base of mantle lithosphere, because of cooling of the uppermost asthenosphere far from the ridge. This last process occurs when the geotherm drops below $1050^{\circ} \mathrm{C}$ at $3 \mathrm{GPa}$ which yields a $\mathrm{LAB}$ at $\sim 90 \mathrm{~km}$ below which neither pargasite or hydrous carbonate-bearing silicate melt could exist. It gives a thickened lithosphere with the growing layer of subsolidus phlogopite-bearing garnetlherzolite with carbonatite, or graphite $+\mathrm{H}_{2} \mathrm{O}+\mathrm{CH}_{4}$ fluid.

Structural data released by mapping numerous mantle core complexes, mostly immediately westward of active slow-spreading ridges, give strong structural constraints for understanding lithospheric mantle dynamics during plate spreading. Indeed whether in the west or east, these core complexes represent outcrops of mantle and related intrusive gabbro bodies exhumed along the footwall of convex up-wards detachment faults dipping eastward and rooted down to 7-8 $\mathrm{km}$. We interpret these detachment faults as effects of top to bottom asymmetric lithospheric mantle shear, linked to the eastward flowing of asthenosphere delaying the base of the lithosphere moving westward. The usual sill shape of gabbro intrusive bodies is another observation supporting intramantle decoupling during ocean spreading. Furthermore, at the topmost part of the hangingwall of these large detachment faults, a small-scale decoupling occurs between the base of volcanoes and 
symmetric spreading. It follows that whatever the scale, the top to bottom decoupling dynamics enables the exhumation of deep rocks (mantle with or without intrusive gabbro), thus the creation of new surfaces, giving all its meaning to the concept of "detachment-mode of seafloor spreading" developed by Maffione et al (2013). This top to bottom mantle decoupling preserves totally magnetic anomalies recorded at the surface on each side of the axis.

Considering all these results, the mantle lithosphere composition can evolve differently on each side of the ridge, coming from a permanent refertilisation of the western plate whereas the eastern plate just preserves the barely refertilized feature of a harzburgitic residue generated during asthenosphere partial melting below axial ridge. So rigidity, density to a lesser extent and thickness of the western plate become much higher, whereas the shallower bathymetry of the east flank of the ridge is explained by isostatic adjustment because of a somewhat lower density. Also as the eastern plate mantle is lighter and more viscous, there is a higher coupling at the lithosphere-asthenosphere boundary, determining a slower velocity of the eastern plate during ridge migration. The top to bottom and west to east internal decoupling of the mantle lithosphere, linked to its westward drift above the asthenospheric mantle flowing eastward, explains detachment faults and related mantle core complex exhumation.

The petrology of asthenospheric mantle is known experimentally since asthenosphere is the mantle reservoir, at distinct P-T-depths, of MORB (lower asthenosphere) and intraplate basalts (middle to upper asthenosphere). An asymmetric "incipient melt + solid" mantle zone, the LVZ, exists between 230 and $100 \mathrm{~km}$, being much more developped and more fertile westward. So MORB are sourced from a lherzolitic mantle in equilibrium at $\approx 250-230 \mathrm{~km} / 7 \mathrm{GPa}$, the ascent of which up to $65-45 \mathrm{~km}$ / 2-1.6 GPa just below the ridge is roughly adiabatic, thus rather fast and without any significant interaction with surrounding crosscut upper asthenosphere. According to the relative "eastward" direction of the asthenospheric mantle flow lines, the diapiric rise of MORB mantle source from lower asthenosphere is significantly oblique and eastward. This mantle transfer is triggered and checked by the suction effect of the spreading ridge, and the westward ridge migration determines a selfperpetuating mechanism for permanently renewing the MORB source mantle, which explains in return the great homogeneity of MORB through time. Synchronously, major mantle transfers within middle to upper asthenosphere come from the lower asthenosphere farther westward and follow the eastward mantle flow lines, slightly slantwise but barely deviated by the suction effect of the spreading ridge. Mantle undergoes incipient melting, except that the interstitial melts percolate laterally and upwards, react with and enrich the upper asthenosphere in water and the most incompatible elements, a possible mantle reservoir for intraplate basalts. This incipient melting zone represents also the lithosphere-asthenosphere decoupling zone affected by shear heating, reducing the $\mathrm{P} /$ depth of intraplate magma genesis. Also the higher shear wave velocity eastward means a density decrease in relation with a somewhat residual feature of the eastern asthenospheric mantle and reflecting a mixing with residual mantle coming from the high degree melting area below the ridge and not accreted to the lithosphere.

\section{Conclusions}

The proposed oceanic plate spreading model shows that numerous asymmetric features observed with geophysics and structural analysis in the first $300 \mathrm{~km}$ below the oceans are consistent with petrological data on upper mantle and basaltic compositions. Our multi-disciplinary study emphasizes the major role of physical and chemical dynamics of the upper mantle for understanding oceanic plate tectonics, and in turn how evolution of both the composition and internal structure of oceanic plates strongly depends at all scales on plate kinematics. Our model suggests that both plate composition and 
kinematics are interdependent on asthenosphere compositional evolution. The spreading of an ocean, synchronous with the migration of the mid-oceanic ridge, induces a complete and permanent material renewal, by mass transfer at all scales, particularly in the shallow $300 \mathrm{~km}$ of the Earth's mantle below the whole width of the oceans. Another major concept is that all petrological processes, occurring during different types of solid or/and liquid mantle mass transfers, ultimately lead to the genesis of a more or less fertile mantle composition, i.e. a lherzolite but secondary in nature (residual harzburgite refertilized by melt interaction), which is the main composition of the first $300 \mathrm{~km}$ of the Earth below oceans and most likely the continents as well. Incompatible trace elements abundances and isotopic values of mantle sources will necessarily vary from one specific mantle site to another reflecting the detailed individual geological histories of 'lherzolites'.

\section{Acknowledgments}

We are grateful for fruitful and helpful discussions to David H. Green, Don Anderson, Eugenio Carminati, Marco Cuffaro and Giuliano Panza. F. Chalot-Prat is grateful to the CRPG for its financial support to allow brainstorming meetings between the authors of this paper. We gratefully acknowledge David H. Green for his thorough, very constructive and interesting review that helped us to deepen our observations and our model, and to an anonymous reviewer for his numerous pertinent remarks and his careful and patient work on the form of the text, usefully clarifying the content and form of this multi-disciplinary study. Our warm thanks go to Marco Scambelluri for his extensive work during the reviewing process and all his attention as editor of this paper. The data used are listed in the references. This is the CRPG-CNRS contribution no. 2433.

\section{References}

Abily, B., Ceuleneer G. 2013. The dunitic mantle-crust transition zone in the Oman ophiolite: Residue of melt-rock interaction, cumulates from high-MgO melts, or both? Geology, 41, 67-70. Doi :10.1130/G33351.1

Afonso, J. C., Fernandez M., Ranalli G., Griffin W. L., Connolly J. A. D. 2008. Integrated geophysical-petrological modeling of the lithosphere and sublithospheric upper mantle: Methodology and applications, Geochem. Geophys. Geosyst., 9, Q05008, doi:10.1029/2007GC001834.

Anderson, D.L., 2007. New Theory of the Earth, Cambridge University Press.

Anderson, D.L., 2010. Hawaii, boundary layers and ambient mantle-geophysical constraints. J. Petrology, doi: 10.1093/petrology/egq068.

Bonatti, E., Ligi M., Brunelli D., Cipriani A., Fabretti P., Ferrante V., Ottolini L. 2003. Mantle thermal pulses below the Mid Atlantic Ridge and temporal variations in the oceanic lithosphere, Nature, 423, 499-505.

Bostrom, R.C., 1971. Westward displacement of the lithosphere. Nature 234, 536-538.

Brune S., Heine, C., Pérez-Gussinye M., Sobolev S.V. 2014. Rift migration explains continental margin asymmetry and crustal hyper-extension. Nature Communications, 5:4014, doi:10.1038/ncomms5014.

Canales, J.P., Carton, H., Carbotte, S. M., Mutter, J.C., Nedimovi'c, M.R., Xu, M., Aghaei, O., Marjanovi'c, M., Newman, K., 2012. Network of off-axis melt bodies at the East Pacific Rise. Nature Geoscience, 5, 279-283.

Cannat, M., 1993. Emplacement of mantle rocks in the seafloor at mid-ocean ridges. Journal of Geophysical Research, Solid Earth, 98, B3, 4163-4172. 
Carbotte, S.M., Small C. Donnelly K. 2004. The influence of ridge migration on the magmatic segmentation of mid-ocean ridges, Nature, 429, 743-746.

Carey, S.W., 1958. Continental Drift—A symposium (Univ. of Tasmania, Hobart, March 1956), $177-$ 363.

Chalot-Prat, F, 2005. An undeformed ophiolite in the Alps: field and geochemical evidences for a link between volcanism and shallow plate tectonic processes. In Plates, Plumes \& Paradigms, edited by G.R. Foulger, D.L. Anderson, J.H. Natland and D.C. Presnall, Geological Society of America, Special Paper 388, 751-780.

Chalot-Prat, F., Falloon T. J., Green D. H. Hibberson W. O., 2010. An experimental study of liquid compositions in equilibrium with plagioclase + spinel lherzolite at low pressures $(0 \cdot 75 \mathrm{GPa})$. Journal of Petrology, 51(11), 23-49-2376.

Chalot-Prat, F., Falloon T. J., Green D. H., Hibberson W. O., 2013. Melting of plagioclase + spinel lherzolite at low pressures $(0.5 \mathrm{GPa})$ : An experimental approach to the evolution of basaltic melt during mantle refertilisation at shallow depths. Lithos, 172-173, 61-80.

Conder, J.A., Wiens, D.A., 2006. Seismic structure beneath the Tonga arc and Lau backarc basin determined from joint Vp, Vp/Vs tomography. Geochemistry, Geophysics, Geosystems 7, Q03018.

Crespi, M., Cuffaro, M., Doglioni, Giannone, C., Riguzzi, F., 2007. Space geodesy validation of the global lithospheric flow. Geophysical Journal International, 168, 491-506, doi: 10.1111/j.1365-246X.2006.03226.x.

Cuffaro, M., Doglioni, C., 2007. Global kinematics in deep versus shallow hotspot reference frames, In: Foulger, G.R., and Jurdy, D.M. (Eds.), Plates, plumes, and planetary processes: Geological Society of America Special Paper 430, 359-374, doi: 10.1130/2007.2430(18).

Dijkstra, A.H., Drury, M.R., Visser, L.R.M., 2001. Structural petrology of plagioclase peridotite in the West Othris mountains (Grece): melt impregnation in mantle lithosphere. Journal of Petrology 42, 5-24.

Dick, H.J.B., Natland, J.H. 1996. Late-stage melt evolution and transport in the shallow mantle beneath the East Pacific Rise, in Mével, C., et al., eds. Proceedings of the Ocean Drilling Program, Scientific Results, 147:College Station, Texas, Ocean Drilling Program, 103-134.

Doglioni, C., Carminati, E., Bonatti, E., 2003. Rift asymmetry and continental uplift. Tectonics, 22, 1024-1037, doi:10.1029/2002TC001459

Doglioni, C., Carminati, E., Cuffaro, M., Scrocca, D., 2007. Subduction kinematics and dynamic constraints. Earth Science Reviews, 83, 125-175, doi:10.1016/j.earscirev.2007.04.001.

Doglioni, C., Green, D.H., Mongelli, F., 2005. On the shallow origin of hotspots and the westward drift of the lithosphere. In: Foulger, G.R., Natland, J.H., Presnall, D.C., and Anderson, D.L. (Eds.), Plates, plumes, and paradigms: Geological Society of America Special Paper 388, 735-749, doi: 10.1130/2005.2388(42).

Doglioni, C., Ismail-Zadeh, A., Panza, G., Riguzzi, F. 2011. Lithosphere-asthenosphere viscosity contrast and decoupling, Physics of the Earth and Planetary Interiors, 189, 1-8.

Doglioni, C., Anderson, D.L., 2015. Top driven asymmetric mantle convection. In The Interdisciplinary Earth: A volume in honor of Don L. Anderson. Geological Society of America Special Paper 514, American Geophysical Union Special Publication 71, doi:10.1130/2015.2514(05).

Doglioni, C., Panza, G.F., 2015. Polarized plate tectonics. Advances in Geophysics, 56, 3, 1-167, http://dx.doi.org/10.1016/bs.agph.2014.12.001 
816 Eggins, S. M., 1992a. Petrogenesis of Hawaiian tholeiites: 1. Phase equilibria constraints. Contributions to Mineralogy and Petrology 110, 387-397.

Eggins, S. M., 1992b. Petrogenesis of Hawaiian tholeiites: 2. Aspects of dynamic melt segregation. Contributions to Mineralogy and Petrology110, 398-410.

Eiler J.M., Schiano, P., Kitchen, N., Stolper E.M., 2000. Oxygen-isotope evidence for recycled crust in the sources of mid-ocean-ridge basalts. nature, 403, 530-534.

Falloon, T. J., Danyushevsky, L. V., Ariskin, A., Green, D. H., 2007a. The application of olivine geothermometry to infer crystallization temperatures of parental liquids: implications for the temperature of MORB magmas. Chemical Geology 241, 207^233.

Falloon, T.J., Green, D.H. Danyushevsky, L.V. 2007b. Crystallization temperatures of tholeiite parental liquids: Implications for the existence of thermally driven mantle plumes, in Foulger, G.R., and Jurdy, D.M., eds., Plates, plumes, and planetary processes: Geological Society of America Special Paper 430, 235-260, doi:10.1130/2007.2430(12)

Frey, F.A., Green, D. H., 1974. The mineralogy, geochemistry and origin of therzolite inclusions in Victorian basanites. Geochimica et Cosmochimica Acta, 38, 1023-1059.

Fyfe, W.S., 1960. The possibility of $d$-electron coupling in olivine at high pressures. Geochimica et Cosmochimica Acta, 19, 141-143.

Green, D. H., 1971. Composition of basaltic magmas as indicators of conditions of origin: application to oceanic volcanism. Philosophical Transactions of the Royal Society of London, A 268, 707-725.

Green, D. H., Falloon, T. J., 1998. Pyrolite: A Ringwood concept and its current expression. In: Jackson INS (ed) The Earth's mantle: composition, structure and evolution. Cambridge University Press, Cambridge, pp 311-380.

Green, D. H., Falloon, T. J., Eggins, S. M., Yaxley, G. M., 2001. Primary magmas and mantle temperatures. European Journal of Mineralogy 13(3), 437-451.

Green, D. H., Falloon, T. J., 2005. Primary magmas at mid-ocean ridges, 'hotspots', and other intraplate settings: Constraints on mantle potential temperature. In: Foulger, G. R., Natland, J. H., Presnall, D. C. \& Anderson, D. L. (eds) Plates, Plumes, and Paradigms. Geological Society of America, Special Papers 388, 217-247.

Green, D. H., Falloon, T. J., (2015), Mantle-derived magmas: intraplate, hot-spots and mid-ocean ridges, Sci. Bull. , doi:10.1007/s11434-015-0920-y

Green, D.H., Hibberson, W.O., Kovacs, I., Rosenthal, A., 2010. Water and its influence on the lithosphere - asthenosphere boundary. Nature 467, 448-451. doi:10.1038/nature09369.

Green, D.H., Hibberson, W.O., Kovacs, I., Rosenthal, A., 2011. Water and its influence on the lithosphere-asthenosphere boundary, 467, 448-451, 2010). [Addendum.]. Nature 472(7344), 504.

Green, D.H., Hibberson, W.O., Rosenthal, A., Kovacs, I., Yaxley, G.M., Falloon, T.J., Brink, F. 2014. Experimental study of the influence of water on melting and phase assemblages in the upper mantle. Journal of Petrology, 55, 10, 2067-2096 doi: 10.1093/petrology/egu050.

Green, D.H., 2015. Experimental petrology of peridotites, including effects of water and carbon on melting in the Earth's uppermantle. Phys Chem Miner 42, 95-102. doi: 10.1007/s00269014-0729-2.

Gripp, A.E., Gordon, R.G., 2002. Young tracks of hotspots and current plate velocities: Geophysical Journal International, v. 150, p. 321-364, doi: 10.1046/j.1365-246X.2002.01627.x.

Hammond, W. C., Toomey, D. R., 2003. Seismic velocity anisotropy and heterogeneity beneath the Mantle Electromagnetic and Tomography Experiment (MELT) region of the East Pacific 
Rise from analysis of P and S body waves, Journal of Geophysical Research, 108, 2176, doi: 10.1029/2002JB001789, B4.

Henstock, T. J., Woods, A. W., White, R. S., 1993. The accretion of oceanic crust by episodic sill intrusion. Journal of Geophysical Research, Solid Earth, 98, 4143-4161.

Harper, G. D., 1985. Tectonics of slow spreading mid-ocean ridges and consequences of a variable depth to the brittle/ductile transition. Tectonics, 4(4), 395-409. doi: 10.1029/TC004i004p00395.

Holmes, A., 1944. Principles of physical geology. In Thomas Nelson and Sons LTD, Edinburgh (ed.).

Jordan, T. H., 1979. Mineralogies, densities and seismic velocities of garnet lherzolites and their geophysical implications, in The Mantle Sample: Inclusion in Kimberlites and Other Volcanics (eds F.R. Boyd and H. O.A. Meyer), American Geophysical Union, Washington D.C. 1-13. doi: 10.1029/SP016p0001

Kaczmarek, M.A., Müntener, O., 2008. Juxtaposition of melt impregnation and high temperature shear zones in the upper mantle; field and petrological constraints from the Lanzo peridotite (Northern Italy). Journal of Petrology 49, 2187-2220.

Kaczmarek, M.A., Müntener, O., 2010. The variability of peridotite composition across a mantle shear zone (Lanzo massif, Italy): interplay of melt focusing and deformation. Contribution to Mineralogy and Petrology 160, 663-679

Lavier, L. L., Manatschal, G., 2006. A mechanism to thin the continental lithosphere at magma-poor margins. Nature 440, 324-328.

Le Pichon, X., 1968. Sea-floor spreading and continental drift. Journal of Geophysical Research, 73, 12, 3661-3697.

Ligi, M., Bonatti, E., Cipriani, A., Ottolini, L., 2005. Water-rich basalts at mid-ocean-ridge cold spots. Nature, 434, 7029, 66-69.

MacLeod, C.J., Searle, R.C., Murton, B.J., Casey, J.F., Mallows, C., Unsworth, S.C., Achenbach, K.L., Harris, M., 2009. Life cycle of oceanic core complexes. Earth and Planetary Science Letters 287,333-344

Maffione, M., Morris, A., Anderson, M.W., 2013. Recognizing detachment-mode seafloor spreading in the deep geological past. Scientific report 3, 2336, doi: 10.1038/srep02336.

Mallows, C., Searle, R. C., 2012. A geophysical study of oceanic core complexes and surrounding terrain, Mid-Atlantic Ridge 13_N-14_N, Geochem. Geophys. Geosyst., 13, Q0AG08, doi:10.1029/2012GC004075.

Moore, G.W., 1973. Westward tidal lag as the driving force of plate tectonics. Geology, 1, 99-100.

Müller, R.D., Roest, W.R., Royer, J.Y., Gahagan, L.M., Sclater, J.G., 1997. Digital isochrons of the world's ocean floor, Journal of Geophysical Research, 102, 3211-3214.

Müller, R.D., Sdrolias, M., Gaina, C., Roest, W.R., 2008. Age, spreading rates, and spreading asymmetry of the world's ocean crust, Geochemistry, Geophysics, Geosystems, 9, Q04006, doi:10.1029/2007GC001743.

Müntener, O., Pettke, T., Desmurs, L., Meier, M., Schaltegger, U., 2004. Refertilization of mantle peridotite in embryonic ocean basins: trace element and Nd-isotope evidence and implications for crust-mantle relationships, Earth and Planetary Science Letters 221, 293308.

Muntener, O., Manatschal, G., Desmurs, L., Pettke T., 2010. Plagioclase peridotites in oceancontinent transitions: Refertilized mantle domains generated by melt stagnation in the shallow mantle lithosphere, Journal of Petrology, 51, 255-294. 
Niu, Y. L., Regelous, M., Wendt, I. J., Batiza, R. and O'Hara, M. J., 2002. Geochemistry of near-EPR seamounts: importance of source vs. process and the origin of enriched mantle component. Earth Planetary Science Letters, 199, 327-345.

Panza, G.F., Doglioni, C., Levshin, A., 2010. Asymmetric ocean basins, Geology, 38, 1, 59-62. doi: $10.1130 / \mathrm{G} 30570.1$

Panza, G.F., Romanelli, F., 2014. Seismic waves in 3-D: from mantle asymmetries to reliable seismic hazard assessment. Earthq Sci 27(5), 567-576, doi:10.1007/s11589-014-0091-y.

Piccardo, G.B., Müntener, O., Zanetti, A., Pettke, T., 2004. Ophiolitic peridotites of the AlpineApennine system: mantle processes and geodynamic relevance, International Geology Review 46, 1119-1159

Piccardo, G.B., Poggi, E., Vissers, R.L.M., 2007a. The pre-oceanic evolution of the Erro-Tobbio peridotite (Voltri Massif, Ligurian Alps, Italy), Journal of Geodynamics 43, 417-449.

Piccardo, G.B., Zanetti, A., Müntener, O., 2007b. Melt/peridotite interaction in the Southern Lanzo peridotite: field, textural and geochemical evidence. Lithos 94, 181-209.

Piccardo, G.B., Guarnieri, L. 2010. The Monte Maggiore peridotite (Corsica, France): a case study of mantle evolution in the Ligurian Tethys. Geological Society, London, Special Publications, 337, 7-45, doi:10.1144/SP337.2

Piccardo, G.B., M. Padovano, and L. Guarnieri (2014), The ligurian tethys: mantle processes and geodynamics. Earth-Science Reviews, 138, 409-434, doi:10.1016/j.earscirev.2014.07.002.

Pilet, S., Baker, M.B., and Stolper, E.M., 2008. Metasomatized lithosphere and the origin of alkaline lavas, Science, 320, 916-919.

Pilet, S., Baker, M.B., Muntener, O. Stolper, E. M., 2011. Monte Carlo simulations of metasomatic enrichment in the lithosphere and implications for the source of alkaline basalts, Journal of Petrology, 52, 1415-1442.

Pilet, S., Hernandez, J., Sylvester, P., Poujol, M., 2005. The metasomatic alternative for ocean island basalt chemical heterogeneity, Earth and Planetary Science Letters, 236, p. 148-166.

Rampone, E., Borghini, G., 2008. The melt intrusion/interaction history of the Erro-Tobbio peridotites (Ligurian Alps, Italy): insights on mantle processes at nonvolcanic passive margins. European Journal of Mineralogy 20, 573-585.

Rampone, E., Piccardo, G.B., Hofmann, A.W., 2008. Multi-stage melt-rock interaction in the Mt. Maggiore (Corsica, France) ophiolitic peridotites: microstructural and geochemical records. Contribution to Mineralogy and Petrology 156, 453-475.

Rampone, E., Piccardo, G.B., Vannucci, R., Bottazzi, P., 1997. Chemistry and origin of trapped melts in ophiolitic peridotites. Geochimica et Cosmochimica Acta 61, 4557-4569.

Rampone, E., Romairone, A., Abouchami, W., Piccardo, G.B., Hofmann, W., 2005. Chronology, petrology and isotope geochemistry of the Erro-Tobbio peridotites (Ligurian Alps, Italy): records of late Palaeozoic lithospheric extension, Journal of Petrology 46, 799-827.

Rampone, E., Hofmann, A.W., 2012. A global overview of isotopic heterogeneities in the oceanic mantle, Lithos 148, 247-261.

Reston, T. J., Ranero, C. R., 2011. The 3-D geometry of detachment faulting at mid-ocean ridges, Geochem. Geophys. Geosyst., 12, Q0AG05, doi:10.1029/2011GC003666.

Ricard, Y., Doglioni, C., Sabadini, R., 1991. Differential rotation between lithosphere and mantle: A consequence of lateral mantle viscosity variations, Journal of Geophysical Research, 96(B5), 8407-8415, doi:10.1029/91JB00204.

Riguzzi, F., Panza, G., Varga, P. Doglioni, C., 2010. Can Earth's rotation and tidal despinning drive plate tectonics? Tectonophysics, 484, 60-73. doi:10.1016/j.tecto.2009.06.012. 
953

954

955

956

957

958

959

960

961

962

963

964

965

966

967

968

969

970

971

972

973

974

975

976

977

978

979

980

981

982

983

984

985

986

987

988

989

990

991

992

993

994

995

996

997

998

Scoppola, B., Boccaletti, D., Bevis, M., Carminati, E., Doglioni, C., 2006. The westward drift of the lithosphere: a rotational drag? Geological Society of America Bulletin, 118, 199-209, doi:10.1029/2004TC001634.

Rosenthal, A., Yaxley, G.M., Green, D. H., Hermann, J., Kovacs, I., Spandler, C., 2014. Continuous eclogite melting and variable refertilisation in upwelling heterogeneous mantle, Scientific Reports 4, 6099, 10.1038/srep06099.

Scheirer, D.S., Forsyth, D.W., Cormier, M.H., Macdonald, K.C., 1998. Shipboard geophysical indications of asymmetry and melt production beneath the East Pacific Rise near the MELT experiment: Science, 280, 1221-1224, doi: 10.1126/science.280.5367.1221.

Shen, Y., Forsyth, D.W., Scheirer, D.S., Macdonald, K.C., 1993. Two forms of volcanism: implications for mantle flow and off-axis crustal production on the west flank of the southern east pacific rise. Journal of Geophysical Research 98, B10, 17,875-17,889.

Shimizu, K., Saal, A.E., Myers, C.E., Nagle, A.N., Hauri, E.H., Forsyth, D.W., Kamenetsky, V.S., Niu, Y., 2016. Two-component mantle melting-mixing model for the generation of midocean ridge basalts: Implications for the volatile content of the Pacific upper mantle. Geochimica et Cosmochimica Acta, 176, 44-80.

Schmerr, N., 2012. The Gutenberg discontinuity: Melt at the lithosphere-asthenosphere boundary, Science 335, 14801483.

Seyler, M., Bonatti, E., 1997. Regional-scale melt-rock interaction in lherzolitic mantle in the Romanche fracture zone (Atlantic Ocean), Earth and Planetary Science Letters 146, 273287.

Small, C., Danyushevsky L. 2003. A plate kinematic explanation for mid-ocean ridge depth discontinuities, Geology, 31, 399-402.

Smith, D.K., Escartín, J., Schouten, H., Cann, J.R., 2008. Fault rotation and core complex formation: Significant processes in seafloor formation at slow-spreading mid-ocean ridges (MidAtlantic Ridge, 13_-15_N), Geochem. Geophys. Geosyst., 9(3), 10.1029/2007GC001699

Smith, D.K., Escartín, J., Schouten, H., Cann, J.R., 2012. Active long-lived faults emerging along slow-spreading mid-ocean ridges, Oceanography 25(1), 94-99, http://dx.doi.org/10.5670/oceanog.2012.07.

Tartarotti, P., Susini, S., Nimis, P., Ottolini, L., 2002. Melt migration in the upper mantle along the Romanche fracture zone (Equatorial Atlantic). Lithos 63, 125-149.

Takahashi, N., (2001), Origin of Plagioclase Lherzolite from the Nikanbetsu Peridotite Complex, Hokkaido, Northern Japan: Implications for Incipient Melt Migration and Segregation in the Partially Molten Upper Mantle. Journal of Petrology 42, 39-54.

Thybo, H., 2006. The heterogeneous upper mantle low velocity zone. Tectonophysics 416, 53-79.

Toomey D.R., Wilcock, W.S.D., Conder, J.A., Forsyth, D.W, Blundy, J.D., Parmentier, E.M., Hammond, W.C., 2002. Asymmetric mantle dynamics in the MELT region of the East Pacific Rise. Earth and Planetary Science Letters 200, 287-295.

Toomey D.R., 2012. Piecing together rifts. Nature Geoscience 5, 235-236.

Vine, F. J., Matthews, D. H., 1963. Magnetic Anomalies Over Oceanic Ridges, Nature, 199(4897), 947-949. doi: 10.1038/199947a0.

Warren, J.M., Shimizu, N., 2010. Cryptic variations in abyssal peridotite compositions: evidence for shallow-level melt infiltration in the oceanic lithosphere. Journal of Petrology 51, 395-423.

Warren, J.M., 2016. Global variations in abyssal peridotite compositions. Lithos, 248-251, 193-219.

Wegener, A., 1915. Die Entstehung der Kontinente und der Ozeae: Samml. Vieweg, Braunschweig, 23, pp 1-94. 
999 White, S.C., Macdonald, K.C., Scheirer, D.S., Cormier, M.H., 1998. Distribution of isolated 1000 volcanoes on the flanks of the East Pacific Rise, $15.3^{\circ} \mathrm{S}-20^{\circ} \mathrm{S}$. Journal of Geophysical $1001 \quad$ Research 103, B12, 30,371-30,384.

1002 Whitney, D. L., Teyssier, C., Rey, P., Buck, W. R., 2013. Continental and oceanic core complexes, 1003 GSA Bulletin, 125, 3/4, 273-298, doi: 10.1130/B30754.1. 
1006 Figure 1. Uninterpreted (above) and interpreted (below). Shear wave velocity (Vs) sections along 1007 the tectonic equator (TE) for the Earth's first $300 \mathrm{~km}$. The mantle is faster and the lithosphere is 1008 thicker in the western side with respect to the eastern side of the three major oceanic ridges, EPR1009 Eastern Pacific Ridge, MAR-Mid-Atlantic Ridge, IR-Indian Ridge. Upper asthenosphere 1010 superposes to low-velocity layer (LVZ), i.e., which is the main decoupling surface between 1011 lithosphere and mantle, allowing net rotation of lithosphere, i.e., a first-order eastward relative 1012 mantle flow, or westward drift of lithosphere. Secondary flow should be related to mantle obliquely 1013 upraised along oceanic ridges. Asymmetry between two sides of ridges is independent from age of 1014 oceanic lithosphere, shown at top in million years (modified after Panza et al., 2010).

1015

Figure 1

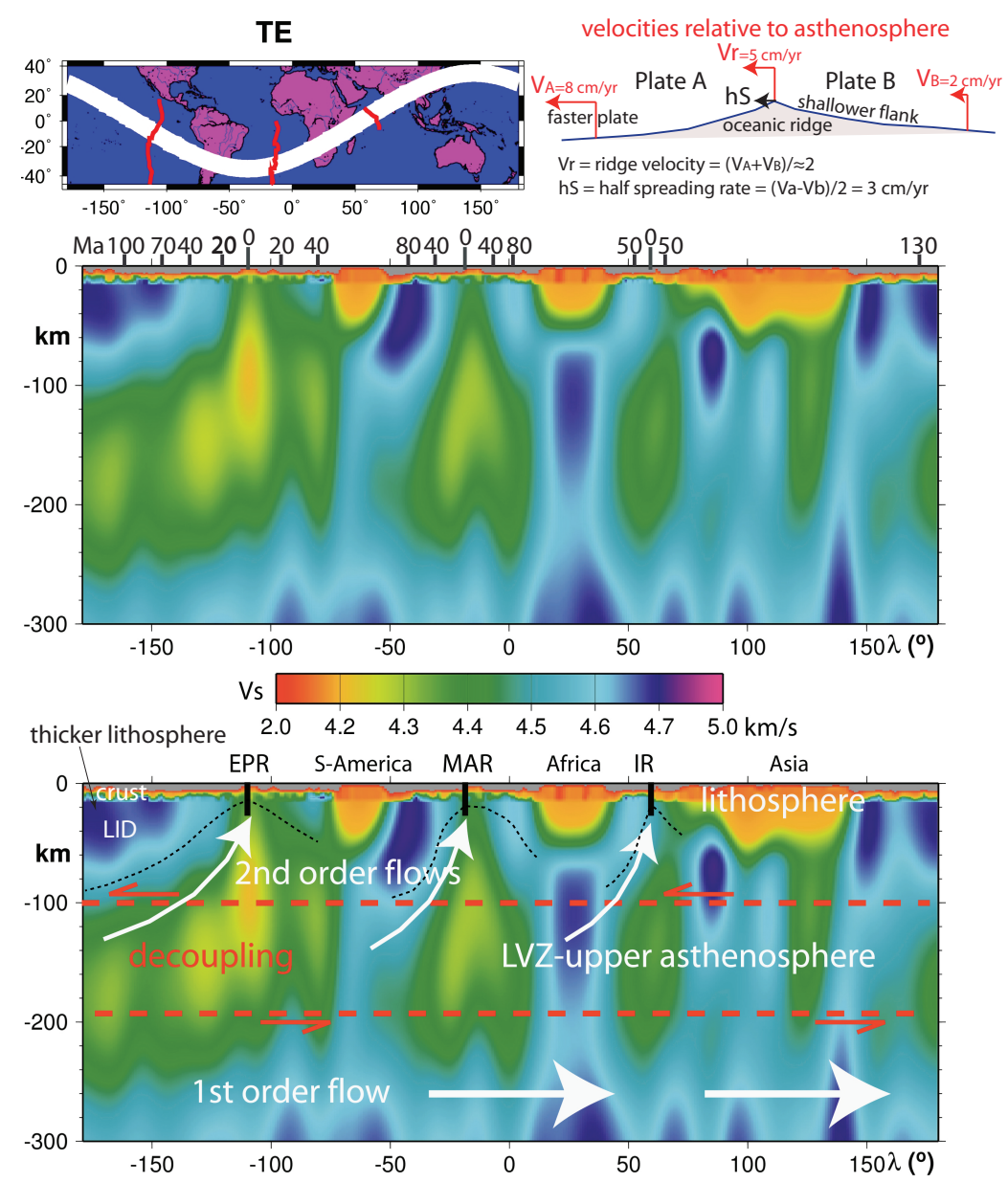


1018 Figure 2. Inferred kinematics of different particles of mantle rocks along a migrating mid-oceanic

1019 ridge, and related asymmetric upper mantle differentiation. Numbers from 1 to $\mathrm{n}$ indicate progressive age evolution of the rock markers within lithosphere and asthenosphere. Plates A and B move with velocity $\mathrm{VA}$ and $\mathrm{VB}$, respectively. $\mathrm{Vr}$ is the velocity of the ridge; $\mathrm{hS}$ is the half-spreading rate. Since the ridge is moving westward, new sections of asthenospheric mantle migrate "eastward" relative to the lithosphere, permanently renewing mantle source of isostatically upwelling magma generated by depressurization below the ridge. During this mass transfer, the eastern part of upper asthenosphere becomes somewhat Fe-depleted, while a top to bottom mantle path decoupling occurs due to the relative "westward" drift of overlying lithosphere. The upper asthenosphere (LVZ) corresponds to the oblique ascent of partially molten mantle from lower asthenosphere. Two different paths of transfer exist: the main one (yellow paths) barely deviated in passing below the ridge, the other (red path) monitored by the suction effect from the strongly depressurized area below the spreading ridge and giving MORB (see Fig. 3 for details). Mantle lithosphere is created at the ridge through accretion of residues above the asthenospheric partial melting area, residues successively transferred upwards and laterally at hS rate within the mantle lithosphere on each side of the ridge. A top to bottom decoupling exists within the mantle lithosphere linked to the slowdown by the eastward underlying flow of asthenosphere, and is responsible for detachment faults and mantle exhumation at the spreading ridge. Besides the mantle lithosphere composition, different on each side of the ridge, comes from a permanent refertilisation of the western plate whereas the eastern plate just preserves the barely refertilized feature of a harzburgitic residue generated during asthenosphere partial melting below axial ridge. See text for more details.

Figure 2
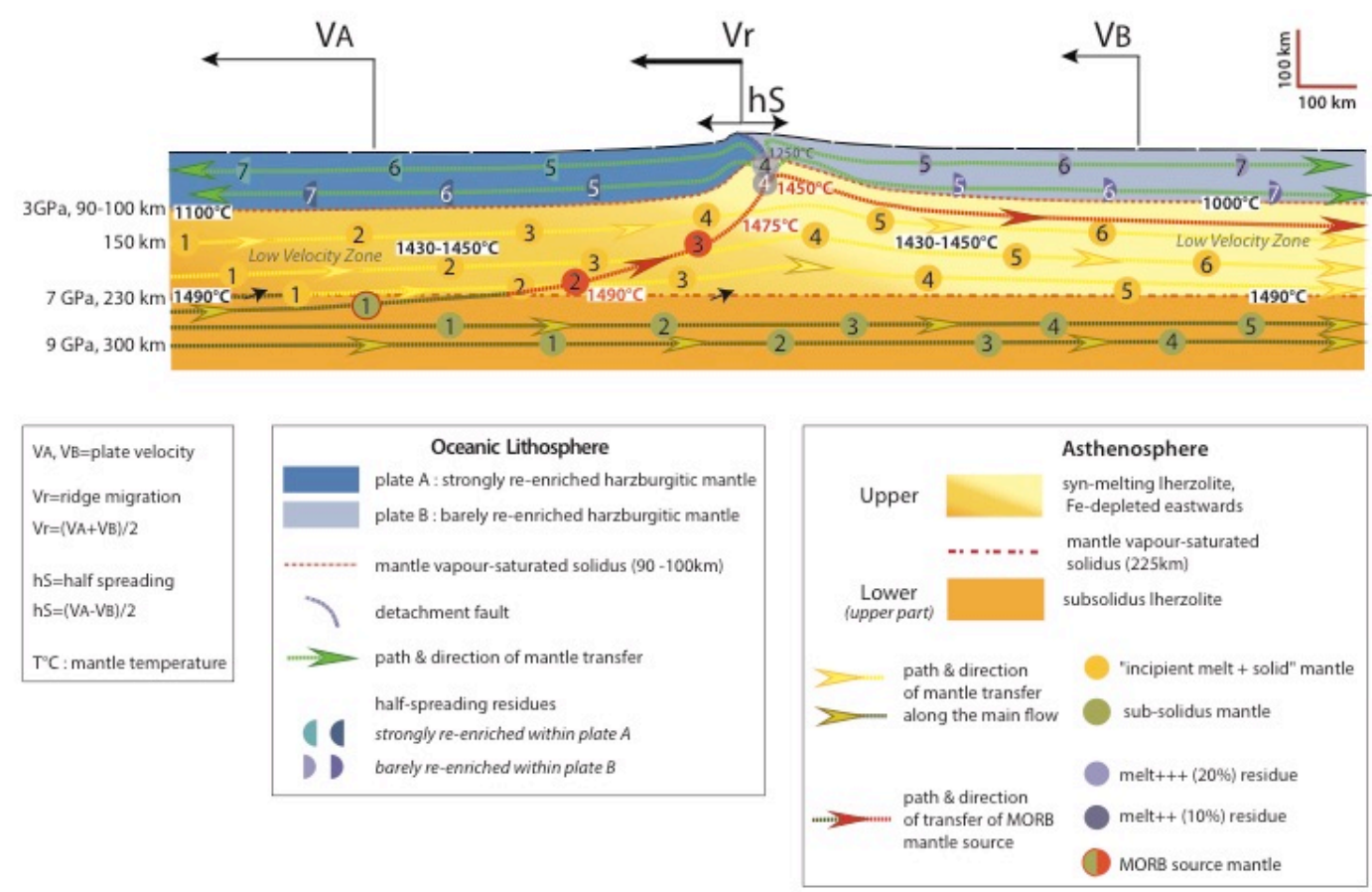
1041 Figure 3. P-T- $\mathrm{H}_{2} \mathrm{O}$ diagrams, modified from Fig. 6 in Green et al. 2014. a) Experimentally 1042 determined solidi for hydrous silicate melt in fertile lherzolite for different water contents; blue 1043 dashed line: mantle adiabat; red star: MORB source mantle upwelling potential temperature at 230, 1044 150, 105 and $65 \mathrm{~km}$; green dashed line: intraplate geotherm; orange dotted line: perturbation of 1045 oceanic intraplate geotherm by shear heating, adapted from Fig. 4 in Doglioni et al. 2005; orange 1046 dot: intraplate magma genesis at shallower depths (105 to $125 \mathrm{~km}$ vs. 110 to $160 \mathrm{~km}$ ) taking into 1047 account shear heating within the lithosphere - asthenosphere decoupling zone. MORB are sourced 1048 from upwelling trace element depleted lherzolite from lower asthenosphere. Intraplate basalts, 1049 including OIB, are the products of upwelling of trace element enriched lherzolite from the middle 1050 and upper asthenosphere. See text for more details. b) Water storage capacity of lherzolitic mantle as 1051 a function of depth along the vapour-saturated solidus. Pargasite becomes unstable at $>3 \mathrm{GPa}$, and 1052 water storage capacity drops to that $(200 \mathrm{ppm})$ which can be retained in NAMs (nominally 1053 anhydrous minerals) in lherzolite, inducing incipient melting of upper asthenosphere (LVZ). See text 1054 for more details.

Figure 3

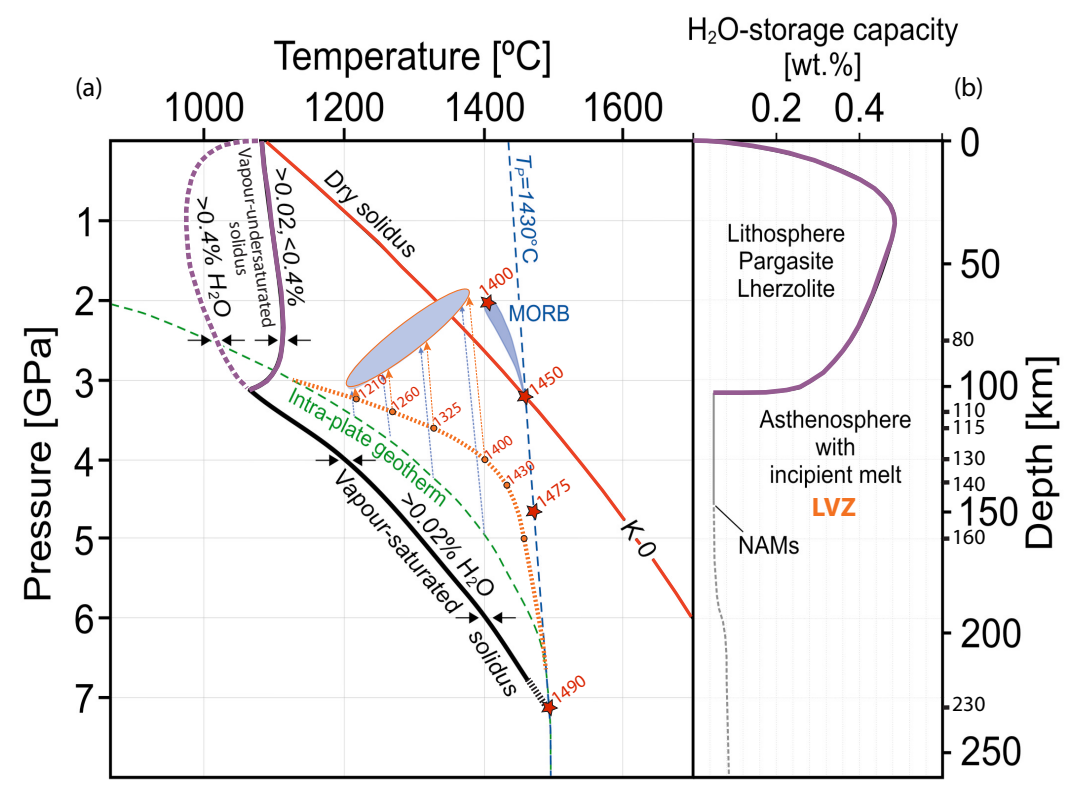

